\title{
Examination of the Attitudes of School of Physical Education and Sports Students towards Teaching Profession in Terms of Various Variables
}

\author{
Turan ÇETINKAYA ${ }^{1}$ \\ Abdurrahman KIRTEPE ${ }^{2}$ \\ Fatih Mehmet UĞURLU ${ }^{s}$ (iD \\ 'Ahi Evran University School of Physical Education and Sports, Turkey \\ Email:turan.cetinkaya@windowslive.com Tel:05337436134 \\ ${ }^{2,3}$ Firat University Sports Sciences Faculty, Turkey \\ Email:abdurrahmankintepe@ogmail.com.Tel:05.537662005 \\ Email:ugurlu76tr@hotmail.com Tel: 05356207177
}

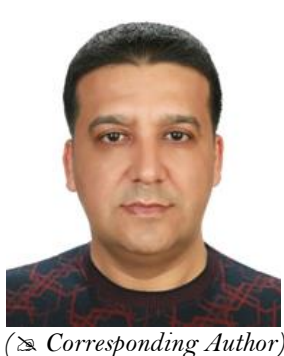

\begin{abstract}
The aim of this research is to determine the attitudes of the students who are studying in the physical education and sports departments towards the teaching profession. 244 students attending Ahi Evran University School of Physical Education and Sports and Firat University Sports Sciences Faculty Physical Education and Sport Teacher Training, Sports Management and Coaching Education departments participated in the research. In the research, personal data form and attitude scale for the teaching profession composed of 34 items were used as data collection means. Distribution, frequency, $t$ test and anova test were performed in the comparison of the related data. Statistical analyzes show that attitudes of participants to the teaching profession do not differ in terms of gender and whether they are teachers in the family, the university in which the training was conducted and the type of sport made.
\end{abstract}

Keywords: Teaching profession, Attitude, College of physical education and sports students, University students.

Citation | Turan ÇETINKAYA; Abdurrahman KIRTEPE; Fatih Mehmet UGGURLU (2018). Examination of the Attitudes of School of Physical Education and Sports Students towards Teaching Profession in Terms of Various Variables. Asian Journal of Education and Training, 4(2): 80-84.

History:

Received: 30 January 2018

Revised: 15 February 2018

Accepted: 20 February 2018

Published: 23 February 2018

Licensed: This work is licensed under a Creative Commons

Attribution 3.0 License (cc)

Publisher:Asian Online Journal Publishing Group
Contribution/Acknowledgement: All authors contributed to the conception and design of the study.

Funding: This study received no specific financial support.

Competing Interests: The authors declare that they have no conflict of interests.

Transparency: The authors confirm that the manuscript is an honest, accurate, and transparent account of the study was reported; that no vital features of the study have been omitted; and that any discrepancies from the study as planned have been explained.

Ethical: This study follows all ethical practices during writing.

\section{Contents}

1. Introduction

3. Results ...u.

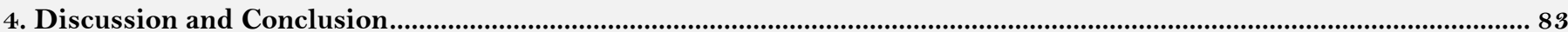

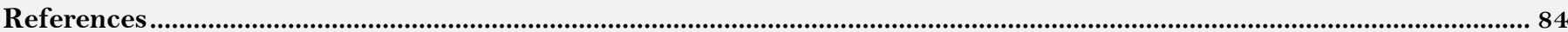




\section{Introduction}

Teaching profession is a profession that undertakes important and difficult tasks such as educating people. This profession, which is a product of humanity and creates societies of the future, is very different from all other professions and specific in its field. Of course, professional attitudes will contribute significantly to the individuals who will be performing this profession so that they can succeed in this particular field and offer human products useful to the societies.

Nowadays, as the greatest source of wealth, well-trained human power is seen. Teachers are also the most important professionals to carry out human rearing. For this, it is necessary for the teachers who are the community architects to be trained in the quality to respond to the needs of the country and the age. Because the development of a country and the increase in the welfare of its members depends on the education of the most important teachers of education and the professional and personal qualities that can best fulfill their duties (Yetim and Göktaş, 2004).

The concept of attitude is seen as a structure, not directly observable because attitude is described as a form of "pre-thought" or "spiritual and nervous preparation". Attitudes have functions such as self-definition, situations, and a summary of feelings, thoughts and behaviors directed at individuals (Feldman, 1996).

Tavşancil (2002) expresses in the form of emotional and mental preparedness which is a direct or dynamic influence force on the behavior of the individual against all the objects and situations which are related, the result of experiences and experiences. Just as most of our behaviors are, our attitudes are gained through learning. Attitudes are part of a person's acquired personality traits and are learned through classical or operant conditioning, such as other acquired personality traits, or by monitoring and imitation of models Morgan (2000). Attitude is not just a thought or feeling. The tendency we define as attitudes includes behavioral cognitions that include emotional and observable activities, including cognitive, emotional, and emotional expressions of self as beliefs (Cüceloğlu, 2000). One of the processes of the teaching profession is attitudes. The source of attitudes, the influence of behavior and its change over time has attracted the interest of social psychologists and has been the subject of many researches (Cüceloğlu, 1996). It can be said that your teacher is a personality profession. Gaining the knowledge and skill required for any profession at the level of expertise generally does not require any other condition to be successful. His special experience; attitudes, behaviors, and attitudes of the students. But it can be said that every attitude, every attitude and every behavior of the teacher is related to its teaching qualities and it directly affects its success (Ataünal, 2003). The extent to which individuals are likely to respond to their surroundings is largely shaped by their attitudes. For an individual, the attitude object can be a matter, a group, or a profession. The attitude of an individual to a profession influences the success and satisfaction of that occupation. When it comes to vocational teaching, the importance of the subject is increasing (Cakir et al., 2000).

When it comes to vocational teaching, the importance of the subject is increasing. Patience, self-sacrifice and continuous work are essential to make this profession lovingly and willingly in order to be successful in the teaching profession (Aşkar and Erden, 1987).

When the related literature is examined, it is possible to find many studies related to attitudes towards the teaching profession, which are related to different variables. When Üstüner et al. (2009) conducted a study on the teaching program from physical education and sport teachers and other fields, the scores of the physical education teacher candidates were higher than the other departments. Pehlivan (2010) reports that physical education teachers' attitudes toward the profession are moderately attitudes towards physical education teachers and that female physical education teacher candidates have higher attitudes than men.

From this point of view, the purpose of this study is to determine whether the attitudes of the students who are studying in the field of physical education and sports to the teaching profession differ according to various variables.

Therefore, the following questions in the research express the hypotheses of researching the questions;

1. Do the participants' attitude scores towards the teaching profession differ from gender perspective?

2. Do the attitude scores of the participants on the teaching profession differ from the point of view of the fact that they are teachers in the family?

3. Do the participants' attitude scores for the teaching profession differ from the university change perspective?

4. Do the participants' attitude points towards the teaching profession differ from the point of view of the type of sports variant?

\section{Material and Method}

\subsection{Universe and Sampling}

The universe of this study was male and female students studying in Ahi Evran University School of Physical Education and Sports and Faculty of Sports Sciences of Firat University in physical education and sports teaching, coaching education and sport management in 2017-2018 education periods. The research population consisted of approximately 1300 students and the sample consisted of 244 students.

\subsection{Data Collection Tool}

Personal information form and validity and reliability study were used as data collection tool in the research. Attitude scale for the teaching profession made by Üstüner (2006) was used. Measuring tool $5=$ Strongly agree, 4 = Agree, 3 = Undecided, $2=$ Not agree, $1=$ Strongly Disagree. The scale is a one-dimensional measure. Since 10 of the scale items contain negative judgments, the data input is transferred to the computer environment. The internal consistency coefficient of the measurement tool is determined by.93. In this study, Cronbach's alpha reliability coefficient of scale was calculated as 86 .

\subsection{Collection of Data}

The questionnaires used in the research were applied to Ahi Evran University Physical Education and Sports College and Frrat University Sports Sciences Faculty Physical Education and Sports Teacher Training, Coaching 
Education and Sports Management students in 2017-2018 education periods. Prior to participating in the study, the athletes involved in the study provided necessary explanations about the purpose of the study and detailed information about filling the data collection vehicle. The data collection tool collected by the researcher was excluded from the investigation by checking and missing or misplaced. Then, the valid and acceptable qualities (244) from the data collection form applied to the participant were transferred to electronic medium by being coded for evaluation.

\subsection{Analysis of Data}

Analysis of data collected in the study was made in SPSS 20.0 statistical package program. In the evaluation of the data; distribution, frequency, $t$ test and anova test. In the tests for the analysis of the data; the principle of equality of variances from the limits of parametric tests is taken as a basis and no significant difference between the groups is sought even if the variances are not equal, even if the value of "p" is less than the significance level. The level of significance in analyzes was determined as $\alpha=0.05$.

\section{Results}

Table-1. Total Score of the Scale

\begin{tabular}{l|l|l|l|l}
\hline Scale & N & Average & Ss \\
\hline Total & 244 & 2,87 & .96 \\
\hline
\end{tabular}

The participants' scores on the attitude scale for the teaching profession were 2.87 and the standard deviation was .96. (Table 1)

Table-2. Factor Loads of Scales

\begin{tabular}{|c|c|c|c|}
\hline & Scale items & $\square$ & $\mathrm{S}$ \\
\hline 1. & It even appeals to me to be a teacher. & 2,92 & 1,69 \\
\hline 2. & The teaching profession is boring to me. & 2,91 & 1,73 \\
\hline 3. & I like being a teacher myself. & 2,85 & 1,68 \\
\hline 4. & If I were to choose a profession again, I would choose teaching again. & 2,90 & 1,62 \\
\hline 5. & I think your teaching is not a profession for me. & 2,93 & 1,71 \\
\hline 6. & I think your teacher does not fit your lifestyle. ${ }^{*}$ & 2,94 & 1,69 \\
\hline 7. & I think your teacher is not suitable for your personality. $*$ & 2,92 & 1,70 \\
\hline 8. & I regret choosing my teaching profession. & 2,93 & 1,74 \\
\hline 9. & I believe that I will succeed in teaching. & 2,92 & 2,08 \\
\hline 10. & I am happy to have chosen this part of the teaching profession. & 2,79 & 1,67 \\
\hline 11. & I believe I can overcome the challenges I face in the teaching profession. & 2,81 & 1,65 \\
\hline 12. & I want to teach even under difficult circumstances. & 2,75 & 1,61 \\
\hline 13. & I am self-confident about the requirements of the teaching profession. & 2,76 & 1,66 \\
\hline 14. & I believe that I have a special ability in teaching. & 2,84 & 1,57 \\
\hline 15. & I think your teaching is not a proper job for me. & 3,06 & 1,69 \\
\hline 16. & I think your teacher will give me opportunities to produce and create something. & 2,88 & 1,58 \\
\hline 17. & I believe that I can practice teaching professionally. & 2,74 & 1,59 \\
\hline 18. & It makes me happy that I will teach people something they do not know. & 2,77 & 1,64 \\
\hline 19. & I sympathize with the people who teach. & 2,80 & 1,64 \\
\hline 20. & It frightens me to think that I will be a teacher. & 2,89 & 1,66 \\
\hline 21. & I do not recommend teaching to those who choose a profession. ${ }^{*}$ & 2,92 & 1,71 \\
\hline 22. & I think there's a lot I can do when I'm a teacher. & 2,73 & 1,66 \\
\hline 23. & The working conditions of your teacher are appealing to me. & 2,80 & 1,63 \\
\hline 24. & I am important to be successful in the teaching profession. & 2,87 & 1,71 \\
\hline 25. & I like to talk to the teachers. & 2,80 & 1,65 \\
\hline 26. & Discusses the issues of education, learning, teaching and teaching, speaking. & 2,82 & 1,60 \\
\hline 27. & I think I will be a knowledgeable and sufficient teacher. & 2,71 & 1,62 \\
\hline 28. & I believe that your teacher will earn me respect in society. & 3,06 & 1,72 \\
\hline 29. & I voluntarily selected the teaching program I am currently studying. & 3,00 & 1,60 \\
\hline 30. & I am concerned that the teaching profession is making me feel tired. & 2,81 & 1,47 \\
\hline 31. & I find it very proud to direct people's life through education through teaching. & 3,01 & 1,62 \\
\hline 32. & I do not like talking about education, learning, teaching, and teaching. ${ }^{*}$ & 3,05 & 1,71 \\
\hline 33. & I believe that the environment will give me enough value when I am a teacher. & 2,85 & 1,57 \\
\hline 34. & The continuity of the teaching profession gives me confidence. & 2,86 & 1,68 \\
\hline
\end{tabular}

'*⿻丷木' Inverse coded elements in the scale.

Table-3. Frequency and percentage distributions of participants' demographic information

\begin{tabular}{l|l|l|l}
\hline Variables & \multicolumn{1}{c}{ Sub Variables } & $\mathbf{f}$ & \% \\
\hline \multirow{2}{*}{ University } & Frrat & 128 & 52.5 \\
\cline { 2 - 4 } & Ahi Evran & 116 & 47.5 \\
\hline \multirow{2}{*}{ Gender } & Male & 127 & 52 \\
\cline { 2 - 4 } & Woman & 117 & 48 \\
\hline \multirow{2}{*}{ Teacher in the family } & There is & 95 & 38.9 \\
& No & 149 & 61.1 \\
\hline \multirow{2}{*}{ The kind of sport you do } & Individual & 120 & 49.2 \\
& Team & 72 & 29.5 \\
& Both of them & 52 & 21.3 \\
\hline Total & \multicolumn{2}{c}{100} \\
\hline
\end{tabular}


A total of 244 students participated in the research, 128 from Firat University and 116 from Ahi Evran University. 127 students were male and 117 were females. The number of students who say that they are teachers in their family is 95 and the number of students who are not teachers in the family is 149 . When the sports students who are educated are found, it is determined that 120 persons engaged in individual sports, 72 persons engaged in team sports and 52 persons interested in sports are determined to be 52 persons. (Table 3 )

Table-4. T-test results of participants' attitudes towards teaching profession towards gender variable

\begin{tabular}{l|l|l|l|l|l}
\hline Gender & N & X & SS & T & P \\
\hline Male & 127 & 2,84 & 0,97 & 0.426 & 0.670 \\
\hline Woman & 117 & 2,90 & 0,96 & & \\
\hline * $<.05$
\end{tabular}

* $\mathrm{p}<.05$

No significant differences were found between the sexes of the students in the study group and the attitudes towards the teaching profession (Table 4).

Table-5. Results of t-tests on attitudes of attendees towards teaching profession versus whether they are family or teacher

\begin{tabular}{l|l|l|l|l|l}
\hline Teacher in the family & N & X & SS & T & P \\
\hline There is & 95 & 2,89 & 0,94 & 1,998 & 0.57 \\
\hline No & 149 & 2,77 & 0,97 & & \\
\hline * $<<.05$
\end{tabular}

There was no statistically significant difference between the level of attitudes of the students to the teaching profession and the variable of being a teacher in their families (Table 5).

Table-6. T-test results of participants' attitudes towards the teaching profession towards the university variable

\begin{tabular}{l|l|l|l|l|l}
\hline University & N & N & SS & T & P \\
\hline Firat & 128 & 2,54 & 0,92 & 6,08 & 0.00 \\
\hline Ahi Evran & 116 & 3,24 & 0,88 & & \\
\hline${ }^{*} \mathrm{p}<.05$
\end{tabular}

It was determined that there was a statistically significant difference between the attitudes of the students in the research group to the teaching profession and the teaching profession (Table 6).

\begin{tabular}{|c|c|c|c|c|c|c|}
\hline Type of sport & $\mathbf{N}$ & Average & Ss & $\mathbf{F}$ & $\mathbf{P}$ & Significant Difference \\
\hline 1.Individual & 120 & 2,64 & 1,00 & \multirow[t]{3}{*}{7,466} & \multirow[t]{3}{*}{$\overline{0,001}$} & \multirow{3}{*}{$\begin{array}{l}1-2 \\
\text { O } 1-3\end{array}$} \\
\hline 2. Teams & 72 & 3,14 & 0,87 & & & \\
\hline 3. Both & 52 & 3,03 & 0,85 & & & \\
\hline
\end{tabular}

The Tukey HSD test was conducted to determine the difference in the level of attitudes towards the teaching profession among the students in the study group $(\mathrm{p}<0.05$, Table 6$)$. The average of individual sports participants is 2.64, while the team is 3.14 for sportsmen and 3.03 for both sportsmen (Table 7).

\section{Discussion and Conclusion}

In this part of the study, the attitudes of the participants towards the teaching profession are given, and these parameters are gender, whether they are teachers in the family, the results related to the sports type variables were discussed and discussed.

According to our research findings, there was no difference between participants' attitudes towards the teaching profession in terms of gender change. When the relevant literature is examined, the results of Küçük et al. (2016) on our study of physical education prospective teachers reached our results in support of our findings and there was no difference in terms of attitude scores and gender variation of the participants. Pehlivan (2010) and Cinpolat et al. (2016) also report attitudes scores of female participants higher than male participants in the study of physical education and sports teacher candidates. These studies differ from our findings in terms of their results. It is possible to come across many studies which have different results from the perspective of gender change, which is formed by different sample teaching programs. The results of Karahan (2005) study indicate that there is no difference between our findings and attitudes of the participants towards the teaching profession in terms of gender change. Again; (Demirtaş et al., 2008; Korkmaz and Usta, 2010; Jaiswal, 2013; Sandıkçı and Öncü, 2013) the studies they have conducted have resulted in parallel results in terms of gender change. Area literature is also available in studies that have obtained different findings in terms of gender variation. (Çapri and Çelikkaleli, 2008; Sağlam, 2008; Çetinkaya, 2009) reported that attitude scores of female teacher candidates were higher and more significant than male candidates in their research. It is thought that the differences in the results of the research may be due to the socio-economic, cultural and regional diversity of the participating groups. According to my research, there is no significant difference between attitude scores of participants according to the variable of being a teacher in the family. Aslan and Köksal-Akyol (2006) indicate that the results of your study in parallel with the study do not make any difference in terms of attitude scores among the participants whether they are teachers in the family. Researchers believe this is the case; families of teachers who are candidates, their families can be considered for vary according to non-teachers, however, have a positive outlook said that and in society generally refers perceived as a respectable profession of teaching for the overall teaching profession to get someone working as a teacher in families in Turkey or not. For this reason, teachers and non-teachers in the family report that the scores of the candidate candidates may not be significantly differentiated. Tanel et al. (2007) and in Kartal and Afacan (2012) they also report that the attitude scores of the participants did not differ according to whether they were teachers 
or not at the time of their studies on the teacher candidates who received pedagogical formation training. The results of the analysis of the participants' attitudes towards the teaching profession towards the university variable in which they were educated showed a significant difference in favor of the students of Firat University. The attitude scores of the students of Firat University Sports Sciences Faculty towards the teaching profession are higher than those of Ahi Evran University Physical Education and Sports College students. This result is thought to be due to the socio-cultural characteristics of the research group. The study, which includes the researcher Dicle and Firat universities, reports that there is no difference between the attitude scores of the teacher candidates in terms of university change. This study differs from our study in terms of findings. According to our findings, physical education and sports teachers' attitudes towards the profession differ in terms of the types of sports they do. Participants' attitudes to individual sports are lower than team sports and participants of both sporting types. These results are thought to originate from the peculiar structure of individual sports. Collaborative elements in team sports and endeavors to achieve integrity for the same purpose differ in many ways from individual sports. Therefore, it is considered that the sport type variable made by the sport can give different characteristics to candidates in terms of professional qualities. In the related literature, studies on attitude scores in terms of sport type are extremely limited. The main focus of the teaching profession is to educate qualified individuals and to provide beneficial citizens with every aspect of gathering. Positive and high attitudes towards this profession, which is such an important and different output from all other professions, will surely provide significant gains in order to achieve this task. Especially, it is important that the institutions that educate teachers in the discipline of physical education and sport sciences should be able to construct such a way that this process student will gain positive attitudes towards the profession during the period of undergraduate education or before the license period.

\section{References}

Aşkar, P. and M. Erden, 1987. Attitude scale of teacher candidates towards teaching profession. Journal of Contemporary Education, 12(121): 8-11.

Aslan, D. and A. Köksal-Akyol, 2006. Examination of preschool teacher candidates' attitudes towards the teaching profession and their professional self esteem. Cukurova University Journal of Social Sciences Institute, 15(2): 51-60.

Ataünal, A., 2003. Why and what kind of teacher?, Ankara: National Education Foundation Publications.

Cakir, Ö., A. Erkuş and F. Kılıç, 2000. Mersin university evaluation of 1999-2000 teaching profession information program (ÖMBP) in terms of various variables. Mersin University Research Fund Accountancy EF (LO) 2000-1 Nolu Research Project.

Çapri, B. and Ö. Çelikkaleli, 2008. Examination of teacher candidates' attitudes towards teaching and gender, program and faculties of professional competence beliefs. Inonu University Education Faculty Magazine, 9(15): 33-53.

Çetinkaya, Z., 2009. Determination of Turkish teacher candidates' attitudes towards teaching profession. Elementary Education Online, 8(2): $298-305$.

Cinpolat, T., F. Alıncak and U. Abakay, 2016. Investigation of attitudes of the students of physical education and sports towards teaching profession. Journal of Gaziantep University Sports Sciences, Gaziantep, 1(1): 38-47.

Cüceloğlu, D., 1996. Human and behavior. 6th Edn., Istanbul: Remzi Bookstore.

Cüceloğlu, D., 2000. Human and behavior. Istanbul: Remzi Bookstore.

Demirtaș, H., M. Cömert and N. Özer, 2008. The relationship between attitudes of teacher candidates towards the teaching profession and self-efficacy perceptions. Proceedings of the International Conference on Educational Science, 1, 23-25 June. Famagusta North Cyprus.

Feldman, R.S., 1996. Understanding psychology. New York: McGraw-Hill.

Jaiswal, P.N., 2013. A study of relationship among teaching efficiency, attitude towards teaching profession and academic achievement of B.Ed. students. Indian Streams Research Journal, 3(3): 1-3.

Karahan, H., 2005. Investigation of geography teachers working in secondary education institutions in terms of teaching attitudes with other teachers. Marmara University Institute of Educational Sciences, MA Thesis, Istanbul.

Kartal , T. and Ö. Afacan, 2012. Investigation of attitudes of teacher candidates related to pedagogical formation education on teaching profession. Mehmet Akif Ersoy University Journal of Education, 12(24): 76-96.

Korkmaz, Ö. and E. Usta, 2010. The relationship between teachers' attitudes towards teaching profession and their perceived interactiontracking concerns and problem solving skills. Turkey Social Research Journal, 3: 1-22.

Küçük, K.S., H. Cihan and E. Öncü, 2016. Physical education teacher candidates' cognitive learning strategies, academic self-sufficiency and attitudes towards teaching profession. Journal of Sports Sciences, 26(3): 77-89.

Morgan, C.T., 2000. Psychology entrance. Ankara: Hacettepe University Department of Psychology Publications.

Pehlivan, Z., 2010. Analysis of physical education self-perceptions and attitudes towards the teaching profession. Education and Science, 35(156): 126-141. View at Google Scholar

Sağlam, O.A., 2008. Attitudes of students in the music teacher department towards the teaching profession. Journal of Education Faculty, $5(1): 59-69$.

Sandıkçı, M. and E. Öncü, 2013. Determination and comparison of competence perceptions and attitudes of the teacher candidates in the field of education with the diggers in relation to the teaching profession. Pamukkale Journal of Sport Science, 4(1): $135-151$.

Tanel, R., S..S. Kaya and Z. Tanel, 2007. Investigation of physics teacher candidates' attitudes towards teaching profession in terms of different variables. Pamukkale University Education Faculty Journal, 2(22): 1-9.

Tavşancıl, E., 2002. Measuring attitudes and data analysis with SPSS. Ankara: Nobel Publication Distribution.

Üstüner, M., 2006. Validity and reliability study of attitude scale towards teaching profession. Educational Administration in Theory and Practice, 45(45): 109-127.

Üstüner, M., H. Demirtaş and M. Cömert, 2009. The attitudes of prospective teachers towards the profession of teaching. Case of Inonu University, Faculty of Education, 34(151): 140-155. View at Google Scholar

Yetim, A.A. and Z. Göktaş, 2004. Professional and personal qualities of the teacher. Kastamonu Education Journal, 12(2): 541-550. 